\title{
Erratum: Auto-memorialisation: Augustus' Res Gestae as slanted narrative
}

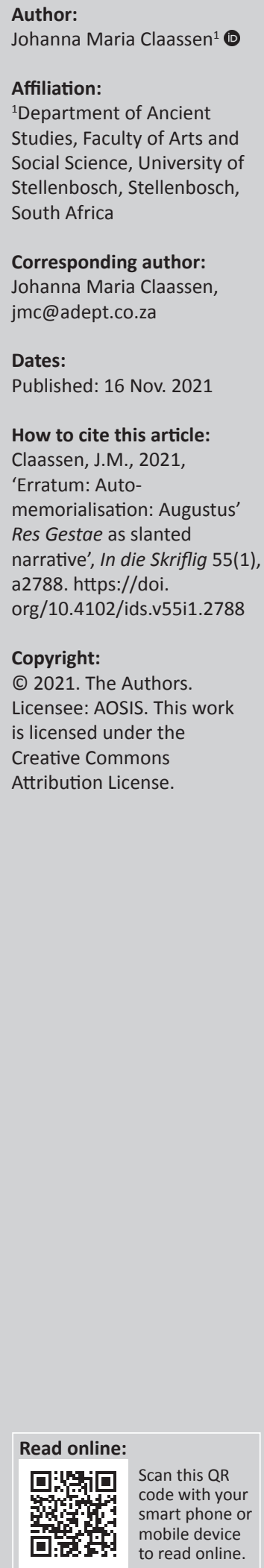

In the version of this article initially published, Claassen, J.M., 2019, 'Auto-memorialisation: Augustus' Res Gestae as slanted narrative', In die Skriflig 53(3), a2442. https://doi.org/10.4102/ ids.v53i3.2442, the article issue number was given incorrectly. The correct issue number should be number 2 instead of number 3.

This correction does not alter the study's findings of significance or overall interpretation of the study results. The publisher apologises for any inconvenience caused. 


\section{Auto-memorialisation: Augustus' Res Gestae as slanted narrative}

\begin{abstract}
Author:
Johanna Maria Claassen ${ }^{1}$ (1)

Affiliation:

${ }^{1}$ Department of Ancient

Studies, Faculty of Arts and Social Science, University of Stellenbosch, Stellenbosch,
\end{abstract} South Africa

\section{Corresponding author:} Johanna Maria Claassen, jmc@adept.co.za

\section{Dates:}

Received: 17 Jan. 2019

Accepted: 03 Apr. 2019

Published: 20 June 2019

How to cite this article:

Claassen, J.M., 2019,

'Auto-memorialisation:

Augustus' Res Gestae as

slanted narrative', In die

Skriflig 53(3), a2442.

https://doi.org/10.4102/

ids.v53i3.2442

\section{Copyright:}

(c) 2019. The Authors. Licensee: AOSIS. This work is licensed under the Creative Commons

Attribution License.

\section{Read online:}

That Augustus wanted to utilise the to-be-publicly-published record of his career, the Res Gestae Divi Augusti, as subtle propaganda, is a well-established critical assumption. While never blatantly inventing 'facts' about his many achievements, the emperor manipulated his brief narrations of individual achievements to fit in with his programme of propaganda. This article not so much explores the 'facts' behind Augustus' categorical assertions of achievements in many spheres, but analyses stylistically his presentation of these facts and his narrative strategies. The exiled poet, Ovid, is shown as one of the first critical readers of the document, his apparent allusions to it seemingly exposing Augustus' often tendentious manipulation of the contrast between 'what happened' and 'how it is told'. The article ends with reference to another critical reader of Augustus' slanted auto-memorialisation.

Keywords: Res Gestae; Emperor Augustus; Autobiography; Slanting of narrative; Narratological strategies; Veracity; Ancient history.

\section{Introduction}

Augustan political and civic discourse has become the focus of various important studies in recent years (Feldherr 2010; Galinsky 1996; Southern 2014²), including analysis of aspects of his 'propagandistic machine'. ${ }^{1}$ This article examines just one of Augustus' various methods of propaganda as an example of deliberate slanting of facts. It ends with the question of how persuasive the picture of his reign was as Augustus held it up before the whole empire, judging from the reactions of two of his contemporaries. My major source is Augustus' selective public statement of his achievements, the Res Gestae Divi Augusti, which was to be erected next to his mausoleum and published widely throughout the Empire. This document will be analysed with especial focus on Augustus' presentation of information that would have been known to his contemporaries, his arrangement and, at times, suppression of relevant facts, concentrating on a stylistic analysis of the presentation of these facts, that is, Augustus' narratological strategies. ${ }^{2}$

Claassen (2016) considers in detail what is meant by the concept Augustan discourse, citing Barchiesi's analysis (1997:15-43) of the relation between political power and literature in Augustus' lifetime. Claassen (2016:57-74) argues that Ovid appropriates aspects of the Augustan discourse to suit his own ends in his exilic poems, deducing that this appropriation paradoxically helped to strengthen Augustus' control over Rome. Particularly important in validating this control was the Res Gestae which, after Augustus' death in 14 CE, was inscribed on panels at the entrance to Augustus' monumental tomb in Rome and elsewhere. The original inscription from the tomb was unfortunately lost. ${ }^{3}$ Transcriptions published throughout the Empire, in both Latin and Greek, served as ultimate publicity for Augustus' achievements. ${ }^{4}$ The best preserved extant version is the inscription known as the Monumentum Ancyranum. ${ }^{5}$ This article will consider the question of whether this auto-memorialisation may be considered 'slanted'.

1.This propagandistic machine developed gradually (for example, see Galinsky 1996; Feldherr 2010; Southern 2014, passim; also see Gurval 1997:39-71 on evidence for the gradual transformation of the sidus lulium 'from star to comet and from sign of Caesar's catasterisation to portent of Augustan greatness'; Pyy 2018 on modern interpretations of Augustus' essential ambiguity; and Syme 1979 on Augustus' progressive change of name).

2.With this I acknowledge a profound debt to all the commentaries consulted. The aim of this article is to collect and categorically re-order such observations with no pretence to offering 'new' historical insights.

3.See in list of References for various editions: for this article, Cooley (2009) as most recent, and Hardy (1923) as representative of earlier approaches, were most frequently consulted. Others consulted include Mommsen's original publication of the document (1883), Dieh $\left(1930^{4}\right)$, Malcovati $\left(1944^{5}\right)$, De Visscher (1965), Brunt and Moore (1967) and Scheid (2007). Malcovati (19445:Iviii-Ixv), Scheid (2007:Ixxviii-Ixxiv) and Cooley (2009:282) list other editions and commentaries.

4.Cooley (2009; cf. Rowe 2011:245) expands on Scheid (2007) which has transliterated facsimiles of both the Latin and Greek versions, parallel versions of the Latin and Greek texts and facsimiles of fragments from Antioch and Apollonia (the latter also in Malcovati 19445:105-149).

5.According to Cooley (2009: 51-55) the Latin version 'returned to Rome' during the Mussolini era. A copy graced the podium of the newly restored Ara Pacis. For Mussolini 'Dux', Augustus' report of his own deeds served to justify a revival of Italy as an imperial force. II Duce's own res gestae were modestly inscribed in Latin nearby.

Note: This contribution is collected as part of the 'Marianne Dircksen Festscrift', sub-edited by Johan Steenkamp (North-West University) 


\section{Background}

Critics offer different dates for the composition of the Res Gestae. The predominance of first-person verbs and its autobiographical colouring indicate composition predating Augustus' death. Tiberius may have edited the text before its dissemination; the Greek paraphrases would have been added locally. ${ }^{6}$ Its present format could have been completed by 2 BCE. Cooley (2009:42, note 243) agrees that an early version could have been circulated from about then. ${ }^{7}$ Claassen (2016:58) argues for Ovid's having been familiar enough with its contents to have made oblique reference to it in various poems from Tomis. Probably parts of this document were abstracted from Augustus' lost 13-book Commentarii de vita sua, a selective description of his career from his youth until the Cantabrian campaigns of 26-25 BCE. ${ }^{8}$ It formed part of Augustus' carefully designed self-presentation, an apologia to 'set the record straight', which presumably (as subsequently did the Res Gestae) not so much dissimulated 'facts', but simply left out aspects contradicting Augustus' selfpromotion as universal 'prince of peace', often blaming his victims for his own reprisals against their actions against himself or his adoptive father.

Cooley (2009:38-42) suggests that the Commentarii were aimed at justifying Augustus' actions to his Roman contemporaries, while the Res Gestae, 'essentially [Augustus'] own funeral eulogium', had a wider propagandistic aim to impress both contemporaries and posterity, emphasising Augustus' rôle in the preservation of the mores maiorum and as champion of the common people. ${ }^{9}$ The Commentarii were probably commonly available from about 23 BCE. Some paragraphs of the Res Gestae could have been based on it; there were probably some overlaps of vocabulary and phrasing.

\section{Narratological analysis?}

The Res Gestae can hardly be considered as falling under either the ancient rhetorical or historiographic genre. Cooley (2009:30-35) discusses precedents for such auto-memorialisation, concluding that Augustus 'created a composition that was sui generis'.$^{10}$ Her (Cooley 2009:36-43)

6.Occasionally the Latin and Greek differ. Comparison is facilitated by juxtapositioning together with translations, inter alia, in Cooley (2009) and Hardy (1923; see Scheid 2007:16 for a stemma).

7.Cooley (2009:42) lists dates for possible 'drafts and emendations': 23, 12 and 4 BCE; 1 , 6 and 14 CE. Scheid (2007:xxii-xxvi) summarises other speculated dating as lying 'between 13 BCE and 9 CE'. Rowe (2011:245) postulates a single final version, dating from 14 CE. Brunt and Moore (1967:6) assume circulation of an early version by 23 BCE (cf. Suet. Aug. 100) with terminus ante quem around 2 BCE (see Heuss 1975:55-94).

8.Lewis (1993:669-688) assumes its continued circulation 'for many generations', serving as source for Appian, Dio and Ulpian, suggesting (on p. 671) that the first part of the commentarii may be reconstructed from the 'lightly hellenised' narrative of Nikolaos of Damascus. Malcovati (19445:xlvi-lii), with annotated testimonia and fragments on pages 84-97, served as a point of departure for Smith and Powell (2009).

9.Cooley (2009:41) suggests that Augustus also meant these as a model for the younger members of his family and the rest of the Roman elite to imitate; perhaps also to justify and propagate the idea of Augustus' own deification.

10.The tradition of self-laudatory monuments ran deep in the ancient world, as witness Pompeius Magnus' list of his achievements on the temple of Minerva (Plin. NH 7.26.97-8). Cooley (2009:31-34) cites various well-known funerary inscriptions and elogia in Rome, Cornelius Gallus' stele at Philae in Egypt, and commemorations on coins as well as early examples from the Near East such as the thorough presentation of the complexities of both its contents and the emperor's aims shows the document as strongly political and in no way objective, although its style projects a false impression of objectivity. In stylistic terms it belongs in the category of 'catalogues' as in the much earlier Linear B documents from Mycenae. However, this tendentious list of Augustus' accomplishments and his beneficence toward all within the Roman sphere was never a business document; its aim was sheer propaganda. My analysis will hence consider Augustus' method of presentation of what he wanted his readers - and posterity - to admire about his life's work. I shall thus concentrate on literary aspects of the document as discourse. Augustus' predecessor, Julius Caesar, was notorious for his manipulations of discourse in the matter-offact 'third party reports' he sent back to Rome during his long series of campaigns in Gaul, presenting in a positive light his military strategies and his efforts at extending Roman sway northwards. The manipulative literary methods followed by his adoptive son and very successful heir were both less subtle (as witness Augustus' use of first-person verbs) and more wide-ranging.

Dircksen (1996:9) indicates that 'narratological analysis' can be applied to narratives only, that is, a story with a beginning, middle and end. Yet, aspects of this approach can be useful here. Augustus' Res Gestae is a collection of 35 paragraphs loosely grouped under a number of nonchronological categories with apparently no strongly distinguishable 'beginnings, middles and ends' - each paragraph in fact representing a small, collapsed 'story' of its own, and the groups in their turn each representing a larger tale. However, Galinsky (1996:42-43) argues that the first three and last two paragraphs (parr. 1-3 and 34-35) are closely linked to form a narrative arc, focusing more on 'interpreting events than describing them'. Historic events are encapsulated and 'shorn of any actual details so as not to obscure their significance' (Galinsky 1996:43). Augustus' manner of presentation of events he wished to stress may still be considered narratologically regarding emphasis ('focalisation'), selection and ordering of events to be enumerated, apparently deliberate non-ordering of references to aspects of time and space, and manipulation of minor characters.

\section{Style}

The well-known Latin educator, Peter Jones, once referred to the Res Gestae as having been written by Augustus 'with all the grace of a concrete mixer'. Admittedly, the Emperor did not attempt many elegant rhetorical flourishes in his bald enumeration (and occasional suppression) of his deeds. But was it entirely graceless? The heading (perhaps, however,

trilingual Bisrun inscription of Darius I ( $522-486$ BCE) of Persia. There are others: Phoenician inscription of King Kulamuwa (ca. 830-820) of the Aramaic kingdom of Sam'al (modern southern Turkey), touts his deeds as 'surpassing those of his predecessors' and on an Old Aramaic inscription, King Bar-Rakib (ca.733-726) boasts of having improved his father's house 'more than any other king' (Hallo et al. 2003:147-148, 160-161). Their existence argues for a common acceptance of et al. 2003:147-148,160-161). Their existence argues for a common acceptance of
the advantages of self-promotion without implying that Augustus was personally aware of these inscriptions. 
composed by another after the death of Augustus) starts with a solemn spondaic hexameter couplet: ${ }^{11}$

Rerum gestarum divi Augusti quibus orbem terrarum imperio populi Romani subiecit ...

[(The report) of the deeds of the divine Augustus whereby

he subjugated the entire world under the sway of the Roman people ...]

Cooley (2009:22) commends 'the conciseness and apparent simplicity with which Augustus expresses himself'. ${ }^{12}$ The first five syllables of the text proper (annos undevi[ginti], 'at age nineteen') display the stylistic mannerism of including all five vowels at the beginning of a text; thereby, according to Cooley (2009:106), 'elevating its literary tone'. Galinsky (1996:10-11) comments on Augustus' 'extraordinary economy of language' and (p. 43) remarks about the opening paragraph: 'Every word here is chosen with utmost deliberation because the sentence is designed to open up the principal and manifold dimensions of Augustus' reign.' The long duration of the second triumvirate and the even longer duration of Augustus' retention of the status of princeps senatus in Res Gestae 7.1 and 2 are emphasised by the postponement of two time clauses to after their respective main verbs (Cooley 2009:133-134).

Throughout, a disarming simplicity of sentence structure tends to obscure rhetorical flourishes such as a triple anaphora of 'ad me' in Res Gestae 31 and 32, climaxing with ' $a m e^{\prime}$ in 33 . Here, sentence structure serves to emphasise the names of subservient near-eastern royals 'tack[ed] on after the main verb' (Cooley 2009:249). In the long list of buildings either built or restored by Augustus (Res Gestae 19) a series of buildings are organised in pairs according to location. These generally reflect the coupling of originally Republican buildings with Augustan structures, culminating in 'a cluster of eight renovations' (Miller 2009:195-196). The structure of the sentence subtly presents Augustus as 're-creator of Republican Rome'. The whole document is equally subtly structured with use of literary allusions and interesting sound play in some passages, according to Cooley (2009:104-106). Perhaps most strikingly, when Augustus in Res Gestae 27 recounts his annexation of Egypt, Armenia (after Artaxes was killed) and other near eastern kingdoms, he makes use of another hexameter couplet (Res Gestae 27.1.1), thereby setting a 'solemn epic tone' (Cooley 2009:229):

Aegyptum imperio populi Romani adieci.

Armeniam maiorem interfecto rege eius Artaxe ...

These 'verses', each with two examples of elision of vowels, do not read very smoothly; their 'rhythmic flow' may be merely coincidental. Yet, a passing Roman, reading aloud the inscription, would of necessity have emphasised their solemn sweep.

11.Cooley (2009:102) refers only to rerum ... orbem as an "hexameter verse', but the next five words may also be read as a rather strained hexameter, hence my 'couplet' with its two elisions.

12.Cooley (2009:23) lists his use of ablative absolutes, frequent asyndeton, paucity of adjectives (which, when they occur, are essential for designating the function of whatever is described, or to emphasise the importance of an achievement), repetition whatever is described, or to emphasise the importance of an achievement), repetition
for the sake of clarity, unusual word order for emphasis, avoidance of Greek loan for the sake of clarity, unusual word order for emphasis, avoidance of Greek loan
words, and use of conventional Roman political terminology in unconventional ways.

\section{Solipsism}

Whereas Julius Caesar forwarded to the Roman people ostensibly 'impersonal' third person reports of the glorious deeds of the magnificent imperator Caesar, Augustus is unapologetically solipsistic. Caesar's reports were presumably generally available on papyrus, but individual readers had to get hold of a copy. Augustus' 'report of his magnificent deeds' was published in bronze for all to read: in Rome, outside the impressive rotunda of his Mausoleum, in the provinces, engraved on the outside walls of public buildings. Even illiterate passers-by might demand of literate friends 'What does it say?' We can, in our turn, ask: 'What would have been the most prominent aspects of Augustus' presentation of his deeds that would have struck the Romansin-the-street most forcibly? Would the same aspects have most impressed their provincial counterparts or would other aspects have been more important, the further away from Rome readers lived?'13

Let us start with the one-dimensional, solipsistic focalisation of the catalogue. In the course of thirty-five separate paragraphs, Augustus uses no fewer than ninety firstperson verbal forms (with the original existence of two more deducible from the Greek, where the Latin inscription is corrupt). Occurrences of *me- and *mi- adjectival and pronominal stems are almost as frequent: eighty-two in all, as against only three cases of *nostr-forms - all these presumably referring to an inclusive 'our', 'of the Roman people'. ${ }^{14}$ The only other active characters in the narrative are Tiberius and Agrippa, both identified in terms of their relationship to Augustus, and, to a less active degree, his first son-in-law. Marcellus, and his (unnamed) grandsons. Significant by their absence are the names of his chief opponents, Brutus and Cassius, Antony and Sextus Pompeius, on whom more below.

Third person verbs are notably rare, although there are many names, both Roman (most often names of consuls cited for purposes of dating) and foreign (names of subjugated or affiliated kings and places brought under Roman hegemony). All these latter are treated as passive, almost lay figures, subservient to the chief aim of the document: to impress its readership with the emperor's great deeds. The seemingly endless jumble of impressive foreign-sounding proper nouns, alternating names of provinces, rivers and stretches of water, tribes and kings in Res Gestae 25-33 did not offer an ordered overview of Mediterranean geography or neareastern politics. An extensive example of the elision or semidistortion of facts (Res Gestae 25-30) uses a brilliant display of names and places included into the Roman hegemonic sphere. A further series of names indicates where Roman influence had also reached various 'independent' territories

13.See Cooley $(2009: 26-30)$ on the Greek versions as not literal translations, but as explanatory adaptations that would speak to provincial sensibilities.

14.Cooley (2009:24-25) comments on the 'revolutionary novelty' of Augustus' use of *me- adjectival forms in referring to the army and fleet, 'smoothly effected via an intermediate step of the army acting meis auspiciis "under my auspices"... mask $[i n g]$ the radical shift' towards control of the 'whole Roman army'. 
(Res Gestae 31-33). ${ }^{15}$ No attempt at dating appears, nor any orderly geographical arrangement from west to east or south to north; the foreign-sounding names of places (some appearing in Latin for the very first time here) seem meant merely to impress passers-by. ${ }^{16}$

At least one contemporary reader of the Res Gestae and the preceding Commentarii seems to have picked up on this apparently deliberate geographical confusion. Augustus' declaration (Res Gestae 30) that, through the agency of his stepson, Tiberius, he defeated and pacified peoples from across the Ister, seems to be picked up in Ovid's Tristia $2.173 \mathrm{ff} ., . .$. [Tiberius] per quem bella geris ... etc. [... through whose agency you wage wars ... etc.]. This claim is countered and refuted by Ovid's every assertion that Tomis is untamed and warlike, and that marauders threaten from across the Ister. Ovid's depiction of Scythia affords contrast with Augustus' 'suppression of a Dacorum exercitus' (Res Gestae 30.2) and his 'achieving the friendship of Bastarnae, Scythae and Sarmatae' (31.2). These are inhabitants of far-flung stretches of southern Russia - in so far as they can be located - here presented in no clear geographical order. Augustus' 'Sarmatians and Bastarnae' (whom Ovid mentions only once, in Tr. 2.198), dwelt some distance from Tomis. Their ferocity, as depicted by Ovid in Tr. 4.8.16, seems to refute Augustus' claim of friendship with them (Claassen 2016:65-67). ${ }^{17}$

\section{Dazzling 'statistical pyrotechnics'}

Earlier paragraphs of the Res Gestae use statistics to similar effect, impressing Augustus' readers with the vastness of his enterprises. ${ }^{18}$ Augustus frequently cites figures, most often cardinals and occasionally ordinals (both sometimes written out as words, but in a few cases presented in Roman figures). On cursory count, 56 cardinal numbers are cited, as against some 18 ordinals and a large number of adjectives and adverbs expressing size more vaguely. Distributives occur: viritim (thrice in Res Gestae 15.1-15.3), or quinto quoque anno (9.1); also adjectives referring to 'large numbers', or inclusivity of various kinds such as aliquot (10.2), universi (14.2), tota (25), omnium (26.1), complures (29.1). Also adverbs denoting frequency occur: semper (9.2), iterum (15.1) or saepe (Res Gestae 31.3), but, more often (about 18 times in all) explicitly numeral adverbs: bis (e.g. Res Gestae 2, 4.4, 22.1), tris (4.1) and more frequently ter $(8.2,13.1,22.1)$, also quarter (17.1, 22.2), quinquiens (22.1), and so on. ${ }^{19}$ All these impressive statistics

15.Cooley (2009:219) comments that this listing seems to negate Augustus' advice to Tiberius to limit Roman sway, ascribing the advice to 'purely temporary pragmatism'.

16.Cooley $(2009: 218-219,222)$ interprets this as inviting 'implicit comparison with Alexander the Great' (cf. Hardy 1923:114-116).

17.On Ovid's approach here, also see Claassen (1999:190-197) and Williams (1994:184-186). For discussion of the tribes of the area and their distance from Tomis, see Syme (1978:166-168) and for Tiberius' campaigns, alluded to in Res Gestae 30, idem, 48-71 (cf. Gruen 1990).

18.Perhaps in emulation of Pompeius Magnus (Plin. NH 7.26.97-98; see note 16 above), who cites 'subjugating 12183000 people', 'capturing 846 ships' and 'annexing 1538 towns', followed by a similar confusion of locations.

19.Such explicit numeral adverbs also serve to modulate cardinals and ordinals - the customary Roman method of expressing large figures. would not only have indicated the size of Augustus' donations to the people or of the various Roman armies (men under arms at any one time),$^{20}$ but would have been a source of wonderment to passers-by, while giving an impression of objectivity. Even the common Roman method of dating by reference to seemingly innumerable pairs of consuls would have added to the impression of the endlessness of the princeps' labours on behalf of his people. Augustus enhances his popular appeal with his statistical pyrotechnics.

A narrative device which relates closely to Augustus's statistical play is his use of ordinals to denote the years of his tribunician power or of his various consulates as alternative or auxiliary method of dating. If listed consecutively, these figures would have been impressive enough, but, as his catalogue of great deeds is arranged categorically and not chronologically, a constant switch back and forth in dating adds to the dazzling effect. On occasion, both methods of dating are employed in a single paragraph, as in Res Gestae 4.4, ${ }^{21}$ beginning Augustus' dating with its terminus ante quem - the time of his composition of the Res Gestae: consul fueram terdeciens cum scribebam haec, et eram septimum et tricensimum tribuniciae potestatis $^{22}$ [I had been consul 13 times when I was writing these things, and holder of tribunician power 37 times].

Various donations to the people out of Augustus' own wealth (Res Gestae 15, at the beginning of the second division of the catalogue), seem to have been carefully arranged, but not by chronology. Scholars have no trouble in dating these various handouts, as Augustus provides the consular date for each (except for Res Gestae 15.1, which is dated by his tribunician power only, perhaps to emphasis his role as 'champion of the people'). In this list, however, a donation during the year $29 \mathrm{BCE}$ to veteran colonists occurs out of logical order between handouts of 5 and 2 BCE (termed by Hardy 1923:80 as 'an afterthought'). Cooley (2009:173) explains it as an attempt to differentiate between disbursements to the citizens of Rome and payments to colonists elsewhere (apparently the largest single amount in any of his payments), and probably also to Antony's veterans after Philippi and Naulochus 'to gain their support'. This is then followed by another listing of small donations to all

20. When added up such figures did not always tally. Hardy 1923.33-34, citing Mommsen (1883 ad loc.), and Cooley (2009:118) comment on the numbers (Res Gestae 3.3). Such discrepancies pale against the dazzling effect on the Roman (Res Gestae 3.3). Such discrepancies
public of such impressive statistics.

21.Both methods of dating also occur together in Res Gestae 15.2. His accession to tribunician power was apparently Augustus' favourite method of dating (e.g. Res Gestae. 4.4; 10.1; 15.1, 2; Cooley 2009:171-2). He wielded such power continuously from 27 BCE onward, only occasionally taking on the consulship, as cited in Res Gestae 1.4; $4.4 ; 8.1-2 ; 15.1,3 ; 20.4$ (sometimes only briefly, also according to Hardy 1923:41-42, ad 4.4). De Visscher (1965:40-41) interprets his tribunician power as the acme of Augustus' powers. On pages 45-46, De Visscher discusses Augustus' progressive arrogation of both positions.

22. Hardy (1923:42) tries to reconcile this information with Augustus' known dates, concluding that Augustus dates his 'permanent' tribunician power to his reconstruction of the principate of $23 \mathrm{BCE}$. Res Gestae 6.1 cites Augustus' threefold rejection of a dictatorship, and preference for tribunician power (which was of equal weight, conferring sacrosanctity and the right of summoning the was of equal weight, conferring sacrosanctity and the right of summoning the
senate and of vetoing bills). Augustus emphasises his fivefold requests for a tribunician colleague. 
those then receiving a corn dole (Res Gestae 15.4). ${ }^{23}$ The composite picture of Augustus' generosity is what is important, rather than its individual parts. This is a typically populistic move.

Augustus' populist image of himself as fatherly benefactor of the Roman people is gradually and carefully built up, starting, of course, with feeding the masses. Augustus' first mention of his intervention in the corn dole (Res Gestae 5.2) merits scrutiny. Paragraphs 5 and 6 list those powers offered to him which he rejected. The first sentence of Res Gestae 5 tells of his refusal of a dictatorship and the third, of a perpetual consulship (Dio 54.10.5). In 5.2 he explains that, when starvation threatened in $23 \mathrm{BCE}$, he accepted a commission as manager of the corn supply, after he had privately and unofficially doled out a supply, purchased with his own funds, in the previous year. Now it was an official appointment and he was administering state funds, which position he augmented with the appointment of two annual assistant curatores annonae and, much later, with a permanent praefectus annonae (Dio 54.1; 55.26). Hardy (1923:45) considers this Augustus' first record of his setting up a permanent office as contrasted with the solution of a passing crisis. With this, Augustus had taken in hand a powerful method of stabilising civilian life (and ensuring lasting popularity) in Rome. It was worth listing as an achievement. Cooley (2009:129) considers that Augustus is deliberately 'both emulating and surpassing Pompey, who had been given command over Rome's corn supply throughout the world for a five-year period'.

\section{Yoking of incidents}

Next we turn to Augustus' most subtle ploy yet: the deliberately propagandistic yoking of incidents to enhance his portrait as 'father of the fatherland' as celebrated in the last paragraph (Res Gestae 35). In several cases, the linking of separate incidents gives a better spin to a story. Res Gestae 13 proudly discourses on the triple closure of the gates of the Janus temple during Augustus' lifetime, indicating the heralding of peace after military strife. The announcement is worded so as to emphasise that under Augustus, a new era has dawned - the gates had been closed only twice before: once under Numa Pompilius, and a second time only briefly after the first Punic War (Livy 1.19.3; Plut. De Fort. Rom. 9 = Mor. 322B). After the defeat of Antony and Cleopatra in $29 \mathrm{BCE}$, the senate voted to close the gates while Octavian was still abroad (Dio 51.20.4). The gates were reopened when Augustus set off to Spain in 27 BCE, but closed two years later (Dio 53.26.5) and remained shut for almost a decade, but were opened at the start of Augustus' campaign in Gaul in 16 BCE. The closure decreed in 11/10 BCE after the victories of Drusus and Tiberius on the northern borders was foiled by the Daci then attacking Pannonia (Dio 54.36.2). A third closure, listed by

23.Cooley (2009:173-174) notes a change within Res Gestae 15 in Augustus description of recipients of his largesse: from plebs Romana, to plebs urbana, to plebs quae tum frumentum publicum accipiebat, 'the common folk who at that time received public grain' - apparently indicating a change in eligibility criteria for such handouts.
Augustus and mentioned by Suetonius (Aug. 22.1), cannot be pinpointed, with resulting confusion about whether it ever took place (Cooley 2009:160).

Negative events are sometimes told in a confused order or linked with more positive ones to mask failure. The admittedly confusing affairs of the Armenian ruling house are briefly reported in Res Gestae 27.2 as having been 'settled' twice: first by Tiberius (who actually, at that time, had retired to Rhodes, according to Dio 55.9.4); and then by Augustus' grandson - his adoptive 'son' - Gaius Caesar (whose subsequent death resulted from Armenian hostilities, Dio 55.10a.5-9; Flor. 2.32.42-45; cf. Cooley 2009:231-232). Hardy (1923:127-131) surmises that, in this paragraph, deliberate gaps in the narrative were aimed at covering over 'failure and confusion'. At Res Gestae 26.5, Augustus coupled, as having taken place 'under his command and auspices' and 'at roughly the same time', two different campaigns: a failed expedition into Arabia Eudamon ('Felix') as far as Mariba under the later disgraced Gallus (Strabo Geog. 2.5.12; 17.1.46), and Petronius' relatively uneventful march southwards along the Nile as far as Meroe (Strabo Geog. 17.1.54). The impression of equal success is achieved by the combination and manipulation of the two narratives: the commencement of both expeditions comes first with a general statement of success in both areas, followed by a more explicit narration of Petronius' African journey, interrupting Augustus' story of 'successful skirmishes' after which Gallus' route in Arabia is briefly described. Cooley (2009:228) comments ad loc. that 'Augustus would doubtless have been very happy for his readers to draw [the] inference [that Gallus had been successful], false though it was'.

\section{Deliberate fudging: Suppression of names and awkward facts}

All of the above devices still largely lie in the realm of 'factuality'. What of deliberate fudging which may be categorised as 'dissimulation'? The best known is Augustus' notorious suppression of the names of the tyrannicides, Brutus and Cassius, in favour of the term factio $^{24}$ in Res Gestae 1, where he also blandly relates having first been made propraetor by the state (res publica) and then consul by the people, suppressing the fact that assumption of these positions at age 19 was highly irregular. The 'villains' are next termed 'Qui parentem meum interfecerunt' (Res Gestae 2). This paragraph departs from the strictly chronological course of events, combining events dating to both before and after Augustus' establishment of the second triumvirate together with Antony and Lepidus (Hardy 1923:31). Cooley (2009:35) cites, as a further example of factual distortion here, and of Augustus' glossing over of awkward truths, his suppression of the fact that the victory at Philippi was actually achieved by Antony, who is never named.

24.Hardy (1932:27) cites, but rejects, Velleius' interpretation (2.61.1) of the term as alluding to Antony. Cooley $(2009: 108)$ considers the possibility that both the tyrannicides and Antony are meant, but also rejects the latter in light of the wording of the Greek version. 
The formation and abandonment of the second triumvirate is disingenuously described. Augustus' narration of the early years of his career as a public figure seems purposely muddled, serving to stress his achievements and the apparently instantaneous growth of his popularity with the Roman people after he started as privatus to act in the public sphere. Galinsky (1996:42-43) stresses that Augustus' 'opening statement' in Res Gestae 1, 'annos undeviginti natus ... private ... private ... in libertatem vindicavi', 'is ... designed to open up the principal and manifold dimensions of Augustus' reign'. Galinsky analyses Augustus' 'interpretation rather than description' of events as relatively bare of details purposely omitted for emphasis. This explains more than it justifies Augustus' telescoping of events and smoothing out of facts that would have spoiled the gradual picture being drawn of a modest, resourceful, capable, selfless, pious, generous private citizen who entered public life in order to avenge his adopted father's death, staying on to rebuild a res publica shredded by internal strife. That is the overarching narrative of the Res Gestae, which could be brilliantly ornamented with impressive statistics, but needed only selective enumeration, not chronological description, of individual events leading to the climactic declaration of this paragon as 'father of the fatherland' in Res Gestae 35. Galinsky (1996:48) refuses to interpret such schematic paradigm-setting as 'deception', remarking cynically that modern political autobiographies 'will not begin ... with outright lies and distortions, but usually wait for at least two or three chapters'.

So the name of Antony, later his opponent, is consciously omitted from Augustus' narrative, enabling two anonymous citations in the first paragraph: first, as part of the hostile 'faction' (Res Gestae 1.2-1.3), and then as a colleague in the second triumvirate (1.4), where the name of the second colleague is also omitted (Cooley 2009:114). Lepidus is only obliquely described - in negative terms - at Res Gestae 10.2, where Augustus celebrates his own appointment as chief priest. ${ }^{25}$ Augustus' dismissive comment, that the unnamed Lepidus '[took] advantage of civil unrest to gain this post in the first place', ignores his own similar actions (for example, his underage achievement of the consulship against senatorial opposition in the first years of his gradual takeover of power). Both colleagues are left unnamed in Res Gestae 7.1, where Augustus elaborates on his being voted triumvir, suppressing the irregularity of the omission of the usual three-day gap between proposal and vote, as well as all mention of the subsequent proscriptions, and the triumvirs' arbitrary appointment of magistrates and priests. ${ }^{26}$

A less tendentious rendition of Augustus' career could have referred to Antony at least thrice more in other contexts. Res Gestae 16.1 describes Augustus' honourable payment for land confiscated for settling veterans without referring to

25. Hardy (1932:65) comments that Augustus "treated Lepidus with as much restrain [here] as in practice;' Cooley (2019:149-151) elaborates on Augustus' subtle ignoring of Lepidus while gradually usurping various religious functions at Rome.

26.Cooley (2009:133) cites App. B Civ. 4.2.7; Dio 47.2.1 and the lex Titia de triumviris rei publicae constituendae (Fasti Coloniani $=$ Inscr. Ital. XIII.i.274 = EJ p. 32). the triumviral custom of simply appropriating such lands, nor to his actions after Actium. At that time he gave his veterans land confiscated from formerly pro-Antonine Italian towns and moved the dispossessed to distant settlements or compensated them with cash. Antony's veterans after Actium were sent even further away (Dio 51.4-6; Cooley 2009:175). None of this is mentioned. Actium is interpreted as a war against the Egyptian queen. Antony remains anonymous in Res Gestae 24.1, although a circuitous reference to is cum quo bellum gesseram [he against whom I had waged war] indicates him clearly enough (Cooley 2009:212; Hardy 1923:109). The final confrontation between Octavian and Antony after the lapsing of the triumvirate, and the murky politics and dubious enlistment methods leading to Octavian's acquisition of an army 'to suppress a conspiracy' are in Res Gestae 25.2 glossed over in a narrative leap - from the conscription of these soldiers, over the ensuing civil war, past the victory over Antony at Actium, to Octavian's exaction of an oath of allegiance from the whole of Italy and various provinces. Augustus' statistics regarding the support of 'more than seven hundred senators' (Res Gestae 25.3) hides the fact that, in a senate that had grown to over 1000 by 29 BCE (Suet. Aug. 35.1; cf. Res Gestae 8.2 and Cooley 2009:217-218), up to 300 senators had supported Antony; Augustus implies that virtually the whole of the senate had been actively on campaign with him. The love-hate relationship between Octavian and Sextus Pompeius, as respective descendants of two of the first triumvirs, is also carefully skirted. Res Gestae 25.1 successfully hides the fact that Augustus's 'pacification of the Mediterranean' involved another episode in the civil war: the war against Pompeius is designated a war against 'pirates and slaves' (Res Gestae 25.1) which ended with their defeat at Naulochus in 36 BCE (Dio 49.1-11.1; Suet Aug. 16.1-3).

There are other examples. Res Gestae 26.3 terms 'banditry' the levying of tolls in the Alpine mountain passes by local tribes - a practice also followed by the Romans (Strabo Geog. 4.6.6-7, Dio 54.22.1-2; cf. Brunt \& Moore 1967:71) and thereby justifying wars fought by Augustus' legates in the area (Suet. Aug. 21.2; cf. Cooley 2009:229). At Res Gestae 29.1, in the list of military standards regained under Augustus' auspices, any reference is omitted to M. Licinius Crassus' recovery in $29 \mathrm{BCE}$ of standards lost to the Bastarnae (Dio $38.10 .3 ; 51.26 .5$ ) - a recovery Augustus could not appropriate for himself. ${ }^{27}$

The names of others are also suppressed, for differing reasons: the Republican general, Scipio Africanus, looms unnamed behind Augustus' listing in Res Gestae 4.4 of his years of tribunician power and his 'correct' application of this right as champion of the people. The tacit implication is that Scipio had virtually dissolved the power of the tribunes at the time of Tiberius Gracchus (Dio 49.15.6, 53.32.5; Livy 38.56.9-10; Cooley 2009:126-8). The name of Augustus'

27.Cooley (2009:241-243) is generally critical of Augustus' reportage of the recovery of standards, dismissing his much vaunted recovery by diplomacy of the standards lost to Parthia by the triumvir, Crassus, as achieved 'by a combination of good luck and effective posturing' 
'father', Julius Caesar, is also suppressed. The awkward fact that Caesar had usurped the dictatorship for life is glossed over in the very next passage (Res Gestae 5.1) where Augustus boasts of his own non-abuse of such a position when offered to him. ${ }^{28}$ Augustus thus manages to imply that perpetual dictatorial power is tantamount to monarchy without impugning his great-uncle. ${ }^{29}$ Similarly, at Res Gestae 12.1, the Roman method of dating by the names of two consuls for a particular year is distorted by Augustus' reference to only one, Q. Lucretius, with the implication that Lucretius had been in power for some time, and thereby disguising the fact that considerable political unrest at the time (19 BCE) had led to Augustus' appointing him as consul without an election (Dio 54.10.3; Velleius 2.94.4).30

\section{Arrogation of the deeds of others}

In a slightly different approach, Augustus simply assumes the role of victorious general in his reporting of any battles fought on his behalf by various military commanders, also identifying as his any of their exploits in civil matters, for example in the battles against the Alpine tribes cited above. When he and Antony were still allied, Antony's two victories against the tyrannicides at Philippi could be claimed as his own, as Augustus asserts in Res Gestae 2, according to Scheid (2007:30), for Augustus' auspices would have been combined with Antony's during the triumvirate. ${ }^{31}$ The next section (paragraphs 3 and 4) is devoted to military successes by land and sea, lumped together in such a way that the numbers granted clemency, the numbers under oath that were settled in towns, and the numbers of ships captured, impress more with their size than their arithmetical consistency. The successful and generous victor is consistently the first person-narrator. Res Gestae 4.1-2 celebrates various types of triumphal ovations, curule triumphs and Augustus' being hailed as 'triumphant general' by his armies, suppressing the names of the military leaders who inevitably fought under his auspices as his 'legates'. Augustus, having consular power, took the auspices daily and hence acted as commanderin-chief - no matter who led the army. ${ }^{32}$

In a civil context, Augustus in Res Gestae 14.1 celebrates honours shown to his adopted 'sons' by the knights and other Roman citizens as if awarded to him. He lists in Res Gestae 15 the many donations to the people made by the imperial family, suppressing, however, at Res Gestae 15.4 a donation of 300 sestertii apiece to the populus 28.This may have occurred several times (Velleius 2.89.5, Suet. Aug. 52).

29.More obviously, readers should not expect to (and do not) find references to Augustus' greatest disappointments, the actions and banishment of the two Juliae and the destruction of a whole Roman legion under Varus.

30.Cooley (2009:153) comments on a discrepancy between the Latin and Greek versions. The Greek translator had apparently noticed the anomalous presentation of facts here.

31.Cooley (2009:115-116) lists variant reasons for his absence from the battlefield as given by different ancient sources: illness, a warning received in a dream by a friend, or skulking in a marsh for three days to avoid the engagement.

32.Compare the 'Gemma Augustea' which illustrates this concept (Cooley 2009:124-125). I cite only some sources Suet. Aug. 22.1; Fasti Triumphales Capitolini: Inscr Ital. XIII.i.87 \& 345; Dio 51.21.5-7; Livy Per. 133; BM Coins. Rom. Emp. I 101, 616-21; Dion. Hal. Ant Rome 2.34.2-4, 54.2, 55.5. For others, see table ' 1 ' in Cooley (2009:122) made by Tiberius when celebrating a triumph in $13 \mathrm{CE}$ (Cooley 2009:173). Similarly, at Res Gestae 20.3, the large role of Agrippa in achieving a 70\% increase in Rome's water supply is suppressed. Sole credit for this is assumed by Augustus, who took over only after the death of this son-inlaw, instituting water commissioners to supervise the, by then, increased water supply. His grandiose claim in the next sentence, namely to have restored 82 temples, conveniently suppresses the fact that the responsibility for the restoration of some was imposed by him upon the descendants of their original founders, often victorious generals of the past (this is Hardy's 1923:97 interpretation of Dio 53.2). ${ }^{33}$

\section{Confusion in census statistics and smuggling in of reference to moral legislation}

Some of Augustus' interventions in Roman civic life were less than successful. One is included in a list of successes, giving it a more favourable aura, even if his description here is itself rather opaque. Augustus' attempts at reordering Roman society feature in Res Gestae 8; the description, with statistics, of various census taken under his auspices, starts with a reference to his increasing the numbers of patricians, inverting the 'normal' SPQR order, iussu populi et senatus, stressing the importance of the common people in such census-taking. The statistics are confusing, indicating in Res Gestae 8.2 an apparent fourfold increase in population since the census of 70 or 69 BCE (Livy Per. 98) and a constant increase from there onward. Roman census criteria could, over time, have been adapted to include women and children (Cooley 2009:141). ${ }^{34}$ Similar confusion prevails in the statistics for Augustus' next two census. The ancient sources, particularly Dio, seem equally confused about the numbers and dates of these (and other) census (Cooley 141-142; Hardy 1923:54-60). The fifth sentence of this paragraph (Res Gestae 8.5) then appears almost as an afterthought: Legibus novis me auctore latis multa exempla maiorum exolescentia iam ex nostro saeculo reduxi et ipse multarum rerum exempla imitanda posteris tradidi [With new, wide-ranging laws I brought back to our era many precedents set by the ancients which were then declining, and I also handed over to posterity exemplary practices for them to imitate].

This boast of reviving obsolescent cultural practices is Augustus' subdued way of referring to his attempted sweeping moral reforms in the controversial leges Iuliae de pudicitia, de adulteriis et stupris and his Lex Iulia et PapiaPoppaea, which had been spectacularly flouted within his own family by the two Juliae. ${ }^{35}$ No mention is made of another venture into social engineering, the Lex Aelia Sentia

33.See Pekary (1975). Claassen (2016:67-68), with n. 68, suggests Augustus' boast may have prompted Ovid to negate it by virtually ignoring the entire Roman pantheon throughout his exilic poetry. Tristia $2.287 \mathrm{ff}$. irreverently celebrates temples as places of assignation.

34.An anonymous reader suggests the enfranchisement of allied troops or subject ally states, could explain discrepancies (cf. Scheidel 2006).

35.Raaflaub and Samons (1990:434-435) consider that this also elicited senatorial opposition. 
of $4 \mathrm{CE}$, restricting manumission, which kept the number of slaves higher and made it harder for young men to marry newly freed women (cf. Gaius 1.19-21).

Earlier, Augustus claims rather obscurely (Res Gestae 6.2), after reporting his 'refusal of an appointment' as curator morum et legum [guardian of laws and customs], that he actually did carry out such duties: 'the things the senate wanted to be accomplished by me at that time, I executed by virtue of my tribunician power'. This seems deliberately vague: what the senate wanted him to do and what he did about it are nowhere clarified. Ovid, on occasion, appears to conflate and echo these claims. ${ }^{36}$ Cooley (2009:131-132) guesses that Augustus is in both passages referring to his moral legislation of $18 \mathrm{BCE}$, but cites a conjecture by WallaceHadrill (regarding Res Gestae 6.2) that he may have been trying to protect Romans' inheritance rights, which would have been a popular move. Augustus' highly irregular possession of perpetual tribunician rights is treated as a given here (Res Gestae 6.2) and cited throughout, as we have seen, as a means of dating that inevitably proclaimed him as perpetual champion of the people - rights later bestowed in turn on Agrippa and Tiberius.

\section{The culmination of Augustus' narrative arc}

The narrative arc of the Res Gestae culminates in two paragraphs depicting the status Augustus enjoyed by the end of his life, which would accrue to his successor. Paragraph 34 of Res Gestae in its entirety treats of all the various powers, in addition to the tribunicia potestas, that accrued to Augustus over his lifetime, starting (Res Gestae 34.1) with his 'gradual transfer of power to the senate and people' in his fifth and sixth consulships (27 to $26 \mathrm{BCE}$ ), which (it is generally accepted) was more a publicity stunt than true abdication of the powers he then held. ${ }^{37}$ The second sentence refers to Augustus' honorific new name and the visible signs of his greatness affixed to the doors of his house, and displayed in the curia Iulia - all these honours accorded him 'pro merito' (Res Gestae 34.2). Cooley (2009:261) interprets this as not referring to a single act, but rather his 'general excellence', or even 'superhuman status'.

Cooley (2009:256) argues that the last two paragraphs of the Res Gestae serve as careful balance, even 'capstone', of the exploits listed in its first three paragraphs; of the characteristics Augustus lists here proudly, his pietas et iustitia hark back to his vindication of Julius Caesar, his clementia to treatment of foreign enemies and his virtus to all the actions described throughout (cf. Lewis 1993: 680-681). ${ }^{38}$ The third sentence of Res Gestae 34 extols the superior auctoritas of the emperor

36.The relation of Tr.2.233-4 to Augustus' marriage laws has been extensively treated by commentators on the poem, for example Barchiesi (1997), Claassen (1999:222), Ciccarelli (2003) and Ingleheart (2010 ad loc). For an overview of Augustus' moral legislation as affecting Ovid, see Barchiesi (2001:155-159), Galinsky (1996:128-140).

37. Recent discoveries of additional fragments have aided scholars towards better interpretation of this passage (Cooley 2009:256-272).

38.See Claassen (2008:116, 120, 124 and 261) on Ovid's use of most of these terms. (translated by Cooley as 'influence' and by Hardy as 'dignity'), implying, however, that he enjoyed 'no more power' (potestatis autem nihilo amplius) than any other senator, the legitimate power deriving from any particular office. However, Augustus' supremacy of influence remained undefined, even 'fuzzy', and he often exercised power even when not officially holding a particular position, as we have seen (Cooley 2009:272). Ovid's ambiguous res est publica Caesar (Tr. 4.4.15) shows this exactly: 'the state is Caesar'. ${ }^{39}$

The last paragraph (Res Gestae 35) announces Augustus' crowning achievement: being universally acclaimed as pater patriae - the 'parent of his country' - in 2 BCE.

Throughout we have noted that Augustus' presentation of the 'facts' of his career verges on dissimulation. Were his contemporaries taken in? At least one Roman, a person equally adept at vesting any utterance with different, even conflicting, shades of meaning, the poet Ovid, often seemed to be questioning Augustan propaganda. ${ }^{40}$ It has, for instance, been argued (summarised in Claassen 2016:62-63) that Ovid's Tr. 4.10 is redolent of subtle polemic against the emperor. Claassen (2016:69-71) discusses Ovid's take on Augustus' much vaunted display of the civic crown and other honours in Tr. 3.1.33-42 as a description of the elevated, quasi-divine status of the emperor and his house as a 'temple'. ${ }^{41}$ Ovid's frequent addresses to the emperor as pater often appear to verge on the irreverent.

Of more importance, however, are the implications for the state of the honours Augustus so proudly extolled in these last two paragraphs. We turn to another Augustan contemporary to judge whether Augustus' slanted narrative was accepted as 'true' and that the monopoly of power it portrayed, was acceptable: his stepson, son-in-law and successor, Tiberius. It seemed obvious that all the cumulative honours listed in Res Gestae 34-35 (which served as tacit acknowledgement of the position of emperor as being tantamount to monarchy) would have automatically passed on to Augustus' successor at his demise. However, Tiberius apparently fought against such a sweeping inheritance of power, only reluctantly acquiescing to assuming the role of princeps. ${ }^{42} \mathrm{He}$ was not alone in his disquiet. Raaflaub and Samons (1990:450) discuss the considerable but ultimately futile opposition to Augustus' various measures, especially from the Senate and intellectuals, citing Tacitus' explanation (Ann. 1.2 and 1.9ff.) that 'the sweetness of peace' had seduced Augustus' opponents into acquiescing in his monopolisation of power.

Levick (1976:74-83) ascribes Tiberius' hesitance, as reported by Tacitus (Ann. 1.6-10) to his awareness, as Augustus'

39.The slippery poet could always resort to blandness: 'Caesar is a public matter', that is, 'an object of interest to all'.

40.Knox (2004:1-20) reckons that by $8 \mathrm{CE}$, Tiberius was so influential that he could prevent any relaxation of Ovid's banishment, '[for Ovid in exile was] still sounding the themes that resonated with Augustus at a time that belonged to Tiberius'.

41.See Cooley (2009:260-270) for discussion and illustrations of the characteristics of these decorations. On Augustus' 'divinity,' see Pollini (1990) and Gradel (2002).

42.Tac. Ann. 1.11.2-13.6, Vell. 2.124.2, Suet. Tib. 24.2, Dio 57.7.1. 
designated successor, of already possessing all the powers implied in the principate. Tiberius apparently was not taken in by Augustus' doublespeak from the mausoleum. He was aware of his predecessor's excessive power and he did not like it. He was trying, according to Levick, to make the Senate realise that all power should not be vested in one man, and was consequently trying to alert them to their own responsibilities - to very little avail. Tiberius was clearly not fooled by Augustus' democratic pretensions, but he had no choice: he was saddled with the monarchic rule Augustus had hidden under a populist masquerade. And he was obliged to publish Augustus' slanted narrative throughout the empire. ${ }^{43}$

\section{Acknowledgements}

It is my pleasure to honour Marianne Dircksen with this article. I owe her a debt for first alerting me to the intricacies of narratological theory and trust that my contribution will not detract from her reputation. Profound thanks to three critical referees whose inputs considerably sharpened my focus.

\section{Competing interests}

The author declares that she has no financial or personal relationship(s) which may have inappropriately influenced her in writing this article.

\section{References}

Barchiesi, A., 1997, The poet and the prince: Ovid and Augustan discourse, University of California Press, Berkeley, CA.

Barchiesi, A., 2001, Speaking volumes: narrative and intertext in Ovid and other Latin poets, London, Duckworth.

Brunt, P.A. \& Moore, J.M. (eds.), 1967, Res Gestae Divi Augusti, Oxford University Press, Oxford.

Ciccarelli, I., 2003, Commento all II libro di Ovidio, Edipuglia, Bari.

Claassen, J.M., 1999, Displaced persons: The literature of exile from Cicero to Boethius, Duckworth, London.

Claassen, J.M., 2008, Ovid revisited: The poet in exile, Duckworth, London.

Claassen, J.M., 2016, 'Seizing the Zeitgeist: Ovid in exile and Augustan political discourse', Acta Classica 59, 52-79.

Cooley, A.E., 2009, Res Gestae Divi Augusti: Text, translation, and commentary, Cambridge University Press, Cambridge.

De Visscher, F., 1965, Les édits d'Auguste découverts à Cyrène, Otto Zeller, Osnabrück.

Diehl, E., 19304, Res gestae Augusti: das Monumentum Ancyranum, De Gruyter, Berlin.

43.The 'Appendix,' a summary of Augustus' expenditure, is written in the third person and appears to have been composed for dissemination in the Greek east (Cooley 2019:276). It was, however, probably commissioned by Tiberius, the ex officio $2019: 276)$. It was, howe
editor of the Res Gestae.
Dircksen, M.R., 1996, 'Narratologiese analise van Tacitus Historiae (I. 1-49)', D. Litt. \& Phil. thesis, Randse Afrikaans Universiteit, Johannesburg.

Feldherr, A., 2010, Playing Gods: Ovid's Metamorphoses and the politics of fiction, Princeton University Press, Princeton, NJ.

Galinsky, G.K., 1996, Augustan culture: An interpretive introduction, Princeton University Press, Princeton, NJ.

Gradel, I., 2002, Emperor worship and Roman religion, Clarendon, Oxford.

Gruen, E.S., 1990, 'The imperial policy of Augustus', in K.A. Raaflaub \& M. Toher (eds.), Between republic and empire: Interpretations of Augustus and his principate, pp. 395-416, University of California Press, Berkeley, CA.

Gurval, R.A., 1997, 'Caesar's comet: The politics and poetics of an Augustan myth', Memoirs of the American Academy in Rome 42, 39-71. https://doi.org/ $10.2307 / 4238747$

Hallo, W., Younger, K.L., Hoffner, H.A. Jr., \& Ritner, R.K. (eds.), 2003, Monumental inscriptions from the Biblical world, Brill, Leiden.

Hardy, E.G., 1923, The Monumentum Ancyranum, Clarendon, Oxford.

Heuss, A., 1975, 'Zeitgeschichte als Ideologie: Komposition und Gedankenführung der Res Gestae Divi Augusti', in E. Burck \& E Lefèvre (eds.) Monumentum Chiloniense: Studien zur Augusteischen Zeit, pp. 55-94, Adolf Hakkert, Amsterdam.

Ingleheart, J., 2010, A commentary on Ovid: Tristia, book 2, Oxford Classical Monographs, Oxford.

Knox, P., 2004, 'The poet and the second prince: Ovid in the age of Tiberius', Memoirs of the American Academy in Rome 49, 1-20, viewed 13 June 2015, from http:// www.jstor/stable/4238815.html

Levick, B., 1976, Tiberius the politician, Croom Helm, London, Sydney, Dover

Lewis, R.G. 1993, 'Imperial autobiography from Augustus to Hadrian', Aufsteig und Niedergang der Römische Welt, II 34(1), 629-706.

Malcovati, H., 19445 ${ }^{5}$ Operum fragmenta Imperatoris Caesaris Augusti, lo. Bapt, Paravia \& Co, Torino.

Miller, J.F., 2009, Apollo, Augustus and the poets, Cambridge University Press, Cambridge.

Mommsen, Th., 1883, Res Gestae Divi Augusti ex monumentis Ancyrano et Apolloniensi, Weidemans, Berlin.

Pekary, T., 1975, 'Statuae meae ... argenteae steterunt in urbe XXC circiter, quas ipse sustuli. Interpretationen zu Res Gestae divi Augusti 24 ', in E. Burck \& E Lefèvre (eds.) Monumentum Chiloniense: Studien zur Augusteischen Zeit, pp. 96-108, Adolf Hakkert, Amsterdam.

Pollini, J., 1990, 'Man or god: Divine assimilation and imitation in the later republic and early principate', in K.A. Raaflaub \& M. Toher (eds.), Between republic and empire: Interpretations of Augustus and his principate, pp. 334-363, University of California Press, Berkeley, CA.

Pyy, E., 2018, The semiotics of Caesar Augustus, Bloomsbury advances in Semiotics, Bloomsbury Academic, London.

Raaflaub, K.A. \& Samons, L.J. II, 1990, 'Opposition to Augustus', in K.A. Raaflaub \& M. Toher (eds.), Between republic and empire: Interpretations of Augustus and his principate, pp. 417-454, University of California Press, Berkeley, CA.

Rowe, G., 2011, Review of A. Cooley, Res Gestae Divi Augusti: Text, translation, and commentary', Journal of Roman Studies 101, 245. https://doi.org/10.1017/ S0075435811000189

Scheid, J, 2007, Res Gestae divi Augusti: hauts faits du divin Auguste, Les Belles Lettres, Paris.

Scheidel, W., 2006, 'The demography of Roman state formation in Italy', version 01, Princeton/Stanford working papers in Classics, viewed 07 March 2019, from https://www.princeton.edu/ pswpc/pdfs/scheidel/040604.pdf

Smith, C. \& Powell, A., 2009, The lost memoirs of Augustus and the development of autobiography, Classical Press of Wales, Swansea.

Southern, P., 2014², Augustus, Routledge, London.

Syme, R., 1978, History in Ovid, Clarendon, Oxford.

Syme, R., 1979, 'Imperator Caesar: A study in nomenclature', in E. Badian (ed.), Roman papers, p. $361 \mathrm{ff}$., Clarendon, Oxford.

Williams, G., 1994, Banished voices, Cambridge University Press, Cambridge. 